\title{
CORPORATE SOCIAL RESPONSIBILITY (CSR) SEBAGAI ACCESS TO JUSTICE BAGI MASYARAKAT LINGKUNGAN PERUSAHAAN
}

\author{
Jejen Hendar \\ Fakultas Hukum Universitas Islam Bandung \\ encep.jejen@gmail.com \\ DOI : https://doi.org/10.29313/sh.v17i1.5358
}

\begin{abstract}
Abtrak
Munculnya aktivitas bisnis yang hanya berorientasi pada keuntungan semata tanpa mempedulikan dampak negatif yang merugikan masyarakat dan lingkungan. Munculnya konsep Corporate Social Responsibility (CSR), analisis stakeholders, dan sejenisnya merupakan respon perusahaan yang telah merugikan masyarakat dan lingkungan, guna mencoba mengembalikan fungsi dan mencoba peduli terhadap sosial dan lingkungan. Hal yang menarik dalam hal ini ialah apakah dengan Corporate Social Responsibiliti (CSR) yang dilakukan oleh perusahaan dapat memerikan jalan menuju keadilan bagi masyarakat sekitar dan lingkungan? Dengan melihat semua kegiatan yang dilakukan oleh perusahaan tersebut. Kegiatan yang dilakukan oleh perusahaan yakni kegiatan CSRnya dirasa merupakan suatu bentuk atau salah satu dari perwujudan acess to justice bagi masyarakat. Hal ini terlihat dari seluruh kegiatan yang dilakukan oleh perusahaan yang memperhatikan kepedulian perusahaan terhadap masyarakat sekitar dan masyarakat umum maupun lingkungan.
\end{abstract}

Kata Kunci: CSR, Access to Justice, lingkungan

\begin{abstract}
The emergence of business activity that simply oriented profits without regard to the negative effects to the detriment of the community and the environment. The emergence of the concept of Corporate Social Responsibility (CSR), an analysis of the stakeholders, and the like is the response company that has been detrimental to society and the environment, in order to try to restore function and try to care about the society and the environment. So the interesting thing in this case is whether CSR made by the company can describe the path to justice for local communities and the environment? By looking at all the activities performed by the company.

Activities performed by the company i.e. it's CSR where activity is a form or one of the embodiment of acess to justice for the community. This is apparent from the whole of the activities conducted by companies that pay attention to the concern of the company towards the local community and the general public as well as the environment.
\end{abstract}

Keywords: CSR, Access to Justice, environment 


\section{PENDAHULUAN}

\section{A. Latar Belakang}

Akhir-akhir ini sering terdengar mengenai isu pemanasan global, penipisan ozon, kerusakan hutan, kerusakan lokasi disekitar areal pertambangan, pencemaran air akibat limbah beracun, pencemaran udara, pencemaran air laut akibat tumpahan minyak dari kapal tangki pengangkut minyak yang bocor, dan sebagainya. Sebagai contoh kejadian yang terjadi di Sidoarjo, Jawa Timur, dimana terjadi kebocoran yang mengakibatkan warga sekitar yang menjadi korban dari kegiatan usaha yang dilakukan oleh perusahaan tersebut.

Contoh lain yakni masih di Sidoarjo ratusan ikan jenis mujair dan juga bader di Sungai Candi, Sidoarjo, Jawa Timur, ditemukan mati diduga akibat pencemaran limbah pabrik yang berada di sepanjang aliran sungai. Dimana menurut aktivis Lembaga Kajian Ekologi dan Konservasi Lahan Basah (Ecoton) M Amir mengatakan, banyaknya ikan mati tersebut diduga akibat pencemaran limbah dari pabrik gula yang dibuang di sepanjang aliran sungai. ${ }^{1}$ Sedangkan menurut harian Kompas mengatakan kontrol laju kerusakan lingkungan hidup di Indonesia rendah. Hutan Indonesia yang diharap menjadi paru-paru dunia telah lama mengalami deforestasi dan degradasi kualitas yang tajam. ${ }^{2}$ setidaknya 3,97 juta hektar kawasan lindung terancam pertambangan, tak luput keanekaragaman hayati di dalamnya. Tak hanya hutan, sungai pun dikorbankan. Jumlah daerah aliran sungai (DAS) yang rusak parah meningkat dalam 10 tahun terakhir. ${ }^{3}$

\footnotetext{
http://www.antaranews.com/berita/321819/ratusan-ikan-mati-diduga-akibat-limbahpabrik di akses pada 20 Januari 2014

2 Kompas 23 Februari "Kontrol Kerusakan Lingkungan Lemah"

${ }^{3}$ Elok Dyah Messwati, Kompas.com "70 Persen Kerusakan Lingkungan akibat Operasi Tambang",
} 
Hal tersebut merupakan akibat negatif dari munculnya aktivitas bisnis yang hanya berorientasi pada keuntungan semata tanpa mempedulikan dampak negatif yang merugikan masyarakat dan lingkungan. Munculnya konsep Corporate Social Responsibility (CSR), analisis stakeholders, dan sejenisnya merupakan respon perusahaan yang telah merugikan masyarakat dan lingkungan, guna mencoba mengembalikan fungsi dan mencoba peduli terhadap sosial dan lingkungan.

Hal yang menarik dalam hal ini ialah apakah dengan Corporate Social Responsibiliti (CSR) yang dilakukan oleh perusahaan dapat memerikan jalan menuju keadilan bagi masyarakat sekitar dan lingkungan? Dengan melihat semua kegiatan yang dilakukan oleh perusahaan tersebut.

\section{B. Rumusan Masalah}

Berdasarkan latar belakang tersebut di atas, maka rumusan masalah yang dikaji adalah bagaimana CSR yang dilakukan oleh perusahaan menjadi access to justice bagi masyarakat sekitar perusahaan?

\section{PEMBAHASAN}

\section{A. Definisi Corporate Social Responsibility (CSR)}

Berikut ini beberapa definisi mengenai definisi CSR, namun secara universal definisi tersebut belum ada yang diterima oleh berbagai lembaga. Beberapa definisi di bawah ini menurut berbagai organisasi yang menunjukan keragaman pengertian, di antaranya yaitu: ${ }^{4}$

\section{World Business Council for Sustainable Development,} mendefinisikan CSR yaitu komitmen berkesinambungan dari kalangan bisnis untuk berperilaku etis dan memberi kontribusi untuk pembangunan

ttps://regional.kompas.com/read/2012/09/28/17313375/70.Persen.Kerusakan.Lingkungan.akibat.O perasi.Tambang.

${ }^{4}$ Edi Suharto, Pekerjaan Sosial Didunia Industri Memperkuat CSR(Coorporate Social Responsibility, (Bandung: Alfabeta.2009), hlm. 103 
ekonomi, seraya meningkatkan kualitas kehidupan karyawan dan keluarganya, serta komunitas lokal dan masyarakat luas pada umumnya. International Finance Corporation memberi sebuah pengertian CSR yakni komitmen dunia bisnis untuk memberi kontribusi terhadap pembangunan ekonomi berkelanjutan melalui kerjasama dengan karyawan, keluarga mereka, komunitas lokal dan masyarakat luas untuk meningkatkan kehidupan mereka melalui cara-cara yang baik bagi bisnis maupun pembangunan. ${ }^{5}$ Institute of Chartered Accountants, England and Wales mendefinisikan bahwa organisasi-organisasi pengelola bisnis mampu memberi dampak positif bagi masyarakat dan lingkungan, serta memaksimalkan nilai bagi para pemegang saham (shareholders) mereka.

Canadian Governance mendefinisikan Corporate Social Responsibility (CSR) dengan kegiatan usaha yang mengintegrasikan ekonomi, sosial dan lingkungan ke dalam nilai, budaya, pengambilan keputusan, strategi dan operasi perusahaan yang dilakukan secara transparan dan bertanggung jawab untuk menciptakan masyarakat yang sehat dan berkembang. European Commission, CSR merupakan sebuah konsep bagaimana perusahaan mengintergasikan perhatian terhadap sosial dan lingkungan dalam operasi bisnis mereka dan dalam interaksinya dengan para pemangku kepentingan (stakeholders) berdasarkan prinsip sukarela. CSR Asia, bahwa CSR adalah komitmen perusahaan untuk berorierasi secara berkelanjutan berdasarkan prinsip ekonomi, sosial dan lingkungan, serta menyeimbangkan beragam kepentingan para stakeholders. ${ }^{6}$

Sedangkan A.S. Susanto mendefinisikan CSR sebagai tanggung jawab perusahaan baik kedalam maupun keluar perusahaan. ${ }^{7}$ Tanggung

\footnotetext{
${ }^{5}$ Ibid., hlm 104.

${ }^{6}$ Ibid., hlm. 105.

${ }^{7}$ Sukisno Agoes dan I Cenik Ardana, Etika Bisnis Dan Profesi tantangan Membangun Manusia Seutuhnya Edisi Revisi, (Jakarta Selatan: Salemba Empat. 2013), hlm. 90
} 
jawab diarahkan kepada pemegang saham dan karyawan dalam bentuk profitabilitas dan pertumbuhan perusahaan, sedangkan tanggung jawab ke luar dikaitkan dengan peran perusahaan sebagai pembayar pajak dan penyedia lapangan kerja, meningkatkan kesejahteraan dan kopetensi masyarakat, serta memelihara lingkungan bagi generasi mendatang.

Menurut ISO 26000 CSR merupakan tanggung jawab sebuah organisasi terhadap dampak dari keputusan dan kegiatannya pada masyarakat dan lingkungan yang diwujudkan dalam bentuk perilaku transparan dan etis dan sejalan dengan pembangunan berkelanjutan dan kesejahteraan masyarakat, mempertimbangkan harapan pemangku kepentingan, sejalan dengan hukum yang ditetapkan dan norma-norma perilaku internasional, serta terintegrasi dengan organisasi secara menyeluruh. ${ }^{8}$ CSR dari definisi di atas dapat didefinisikan sebagai kepedulian perusahaan yang menyisihkan sebagian keuntungannya (profit) bagi kepentingan pembangunan manusia (people) dan lingkungan (planet) secara berkelanjutan berdasarkan prosedur (procedure) yang tepat dan profesional.

\section{B. Corporate Social Responsibility (CSR) sebagai Acess to Justice}

Penegakan prinsip keadilan adalah salah satu ciri dari negara hukum. Keadilan adalah hak dasar manusia yang sejalan dengan prinsip persamaan di muka hukum. Setiap orang memiliki hak untuk memperoleh pemulihan (remedy) atas pelanggaran hak yang mereka derita, sedangkan negaramemiliki kewajiban untuk memastikan pemenuhan hak-hak tersebut. ${ }^{9}$

Ditengah lemahnya peran negara dalam menyediakan pelayanan bagi masyarakatnya, sebagai bentuk dari peningkatan kesejahteraan sosial,

\footnotetext{
8 Ibid... hlm 104.

${ }^{9}$ Kelompok Kerja Akses terhadap Keadilan, Strategi Nasional Akses Terhadap Keadilan, (Badan Perencanaan Pembangunan Nasional (BAPPENAS), Jakarta: 2009)
} 
muncul antusias dari pihak swasta seperti tampak dalam pelaksanaan CSR dari berbagai perusahaan dalam pembangunan kesejahtraan masyarakat. Perusahaan yang telah melakukan CSR memberikan pesan bahwa seharusnya state, civil society dan market memiliki posisi berimbang dalam pembangunan kesejahtraan masyarakat, khususnya di Indonesia. Sepertei halnya yang di ungkapkan oleh mantan Ketua Mahkamah Konstitusi, Jimly Asshiddiqie tentang implikasi amandemen UUD 1945 yang belum banyak disadari oleh masyarakat, menurutnya ada konfigurasi ulang kedudukan negara, masyarakat sipil dan mekanisme pasar. Dalam demokrasi, ketiganya memiliki kedudukan yang sama penting, dimana ketiganya memiliki porsi sepertiga dalam upaya memajukan preadaban, sehingga kedepannyapun peran negara hanya sepertiga. ${ }^{10}$

Kestabilan Politik dan perkembangan positif penegakan hukum, perekonomnian dan kondisi sosial kemasyarakatan diperlukan untuk memperlancar pengembangan CSR yang berkualitas atau disisi lainnya Program CSR diharapkan akan ikut membantu masyarakat dan Pemerintah memprbaiki kondisi dan lingkungan yang berkembang Sejumlah pendapat lama tentang bisnis yang hanya mengejar keuntungan semata (profit) sebagaimana dinyatakan salah satunya oleh Milton Friedman. Bahwa tujuan utama korporasi adalah memperoleh profit semata, semakin ditinggalkan. Sebaliknya, konsep triple bottom line (profit, planet, people) yang digagas John Elkington kini semakin masuk ke mainstream etika bisnis. ${ }^{11}$ Perusahaan yang menjalankan usahanya tidak dibenarkan hanya mengejar keuntungan semata (profit), tetapi juga harus terlibat pada pemenuhan

${ }^{10}$ Harian Republika 24 Maret 2008

11 Nana Sudiana, CSR dan Kepedulian Perusahaan, 2011 dalam http://csr.pkpu.or.id/article/csr-dan-kepedulian-perusahaan dikutip pada 25 Januari 2014 
kesejahteraan masyarakat (people), dan berpartisipasi aktif dalam menjaga kelestarian lingkungan (planet). ${ }^{12}$

Penulis dalam hal ini mencoba mengambil posisi dengan menerapkan apa yang dikemukakan oleh John Elkington dengan konsep triple bottom line (profit, planet, people). Dan memfokuskan kepada dua konsepnya yakni people and planet (masyarakat dan lingkungan). Hal ini penulis melihat bahwasannya kedua konsep CSR ini merupakan suatu acess to justice (akses menuju keadilan), hal ini terlihat ketika kegiatan perusahaan yang menimbulkan dampak negatif baik bagi kehidupan masyarakan maupun lingkunga sekitar perusahaan. Ketika keadilan bagi masyarakat yakni mendapatkan penghidupan yang layak, udara yang sejuk dan segar, dan lingkungan yang bersih, namun dengan adanya perusahaan sebagian hak masyarakat terkurangi, sehingga dengan adanya kegiatan CSR ini diharapkan salah satu benyuk menuju keadilan bagi masyarakat. Ketika konsep ini diterapkan maka diharapkan jalan menuju keadilan ini tercapai, ketika peran pemerintah dalam hal ini negata tidak dapat menjangkau kehidupan masyarakat seluruhnya. Kestabilan Politik dan perkembangan positif penegakan hukum, perekonomnian dan kondisi sosial kemasyarakatan diperlukan untuk memperlancar pengembangan CSR yang berkualitas atau disisi lainnya Program CSR diharapkan akan ikut membantu masyarakat dan Pemerintah memprbaiki kondisi dan lingkungan yang berkembang.

CSR telah banyak dilakukan oleh kalangan perusahaan. Baik perusahan yang bergerak di bidang jasa, konsumsi ataupun yang lainnya. ${ }^{13}$ Jika dipahami mengenai manfaat dari pelaksanaan CSR ini seperti yang

12 Yuli Pujihardi, "Bakar Dahulu, CSR Kemudian” Republika Senin 16 Nov 2015, https://republika.co.id/berita/nxwjsq29/bakar-dahulu-csr-kemudian,

${ }^{13}$ Jejen Hendar, Corporate Social Responsibility (CSR) Dalam Prespektif Hukum Islam, Jurnal Hukum Syiar Hukum, Vol. 15, No. 1 (2017), hlm. 46. 
diungkapakan oleh Wicipto dalam jurnal hukum, menyatakan beberapa manfaat CSR bagi perusahaan, antara lain;

a. Mempertahankan dan mendonkrak reputasi serta citra perusahaan

b. Mendapatkan lisensi untuk beroperasi secara sosial

c. Mengurangi atau memperkecil risiko perusahaan

d. Melebarkan akses sumberdaya bagi operasional usaha

e. Membuka peluang pasar yang lebih luas

f. Mereduksi biaya perusahaan

g. Memperbaiki hubungan dengan pemangku kepentingan (stakeholders)

h. Memperbaiki hubungan dengan regulator

i. Meningkatkan semangat dan produktivitas karyawan

j. Peluang untuk mendapatkan penghargaan.

Untuk melihat bagaimana perusahaan dapat memberikan acess to justice kepada masyarakat sekitar dari bentuk atau kegiatan ataupun konsep CSR yang diterapkan oleh perusahaan tersebut. Dalam hal ini banyak perusahaan yang melakukan tanggungjawab sosial perusahaannya dari berbagai bidang di antaranya: ${ }^{14}$

1. Bidang pendidikan, dalam bidang ini diharapkan dapat memberikan suatu jalan menuju kesuksesan baik dari sudut pandang sosial maupun ekonomi. Dalam perusahaan memberikan dana berupa beasiswa kepada masyarakat yang kurang mampu dan berprestasi. selain berupa beasiswa dapat juga berupa pendidikan kesehatan seperti yang dilakukan oleh PT Unilever Indonesia, Tbk.

Kegiatan yang dilakukan yakni berupa penerapan konsep CSR people, terlihat dari kegiatan yang dilakukan oleh perusahaan berupa pemberian beasiswa kepada masyarakat, hal ini penulis

\footnotetext{
${ }^{14}$ Mukti Faza, "Tanggung Jawab Sosial Perusahaan di Indonesia Studi tentang Penerapan Ketentuan CSR pasa Perusahaan Mulitinasional, Swasta Nasional dan BUMN di Indonesia." (Yogyakarta: Pustaka Pelajar. 2010), hlm. 332-373
} 
melihat dengan adanya kegiatan pemberian beasiswa ini merupakan salah satu jalan menuju keadilan dimana menciptakan masyarakat yang cerdas dan mengetauhi ilmu pengetahuan sebagai bekal untuk memperbaiki hajat hidup masyarakat sendiri.

2. Bidang Kesehatan, bidang ini merupakan bidang yang peduli akan kesehatan dan kebersihan yang ada dalam lingkungan masyarakat, seperti halnya yang dilakukan oleh PT. International Nickel Indonesia Tbk., PT. Bakrie and Brother Tbk. yang memberikan pelayanan kesehatan dan pembinaan kesehatan serta pengembangan fasilitas kesehatan.

Kegiatan yang dilakukan oleh perusahaan dalam pelaksanaan kegiatan di bidang kesehatan penulis melihat hal ini salah satu bentuk akses menuju keadilan terhadap masyarakat, melihat dari data masyarakat miskin di indonesia mencapai 25.674 .580 jiwa $^{15}$, hal ini menunjukan masyarakat miskin di Indonesia sangat banyak. Jika hal ini pemerintah tidak dapat menjangkau seluruh masyarakat miskin, maka dengan adanya kegiatan CSR yang dilakukan oleh perusahaan ini dapat diartikan sebagai akses kepada keadilan bagi masyarakat miskin dalam memenuhi hak asasinya. Yaitu hak mendapatkan pelayanan kesehatan. Seharusnya hal ini berupa pelayanan kesehatan ${ }^{16}$ di lakukan oleh pemerintah. Dengan adanya Kegiatan CSR di bidang kesehatan ini dirasa telah membantu pemerintah dalam mewujudkan salah satu tujuan dari negara ini.

15 2007-2019.html

16 Pasal 28 Ayat (1) H UUD 1945 "Setiap orang berhak hidup sejahtera lahir dan batin, bertempat tinggal, dan mendapatkan lingkungan hidup yang baik dan sehat serta berhak memperoleh pelayanan kesehatan." 
3. Bidang Ekonomi, dengan adanya kepedulian atau tanggung jawab dari perusahaan kepada masyarakat dari segi ekonomi, maka diharapkan dapat membangun dan membentuk ekonomi masyarakat setempat supaya dapat berkembang. Hal ini telah banyak dilakukan oleh berbagai perusahaan di Indonesia seperti yang dilakukan oleh PT Bank Muamalat Tbk.

Pada hasil penelitian yang dilakukan oleh M. Imam Purwandi ${ }^{17}$ dalam disertasinya, menunjukan bahwasannya kegiatan CSR yang dilakukan oleh PT Bank Muamalat Tbk ini melakukan kegiatannya dengan memberikan pinjaman tanpa adanya bunga tambahan. Hal ini sangat membantu masyarakat dalam meningkatkan perekonomian masyarakat untuk menciptakan kesejahteraan ekonomi mereka. Penulis menganggap bahwa kegiatan CSR yang dilakukan oleh perusahaan di bidang ekonomi ini merupakan salah satu akses menuju keadilan bagi masyarakat kecil dalam memenuhi kebutuhan ekonominya guna mencapai kesejahteraan ekonomi.

4. Bidang Lingkungan, hal ini diharapkan dapat memberikan suatu bentuk kepedulian terhadap lingkungan dan sumber daya alam, sehingga ekosistem dan yang lainnya dapat terjaga dan terlestarikan.

Kegiatan dalam lngkungan ini banyak dilakukan oleh perusahaan tambang dan rokok, seperti PT Djarum, PT HM Sampoerna ${ }^{18}$ dan lain sebagainya, kegiatan ini penulis menilai dan beranggapan bahwasannya merupakan salah satu akses terhadap keadilan di

17 Muhammad Imam Purwandi, Al-Qordh dan Al-Qordul Hasan sebagai Wujud Pelaksanaan Tanggung Jawab Sosial Perbankan Syari'ah (Studi Pada PT Bank Muamalat Indonesia Tbk), disertasi (Pasca Sarjana UII, Yogyakarta: 2013).

18 Anual Report 2012 HM Sampoerna 
dalam memenuhi hak mendapatkan lingkungan yang layak dan nyaman.

5. Bidang Sosial, sebagaimana bidang yang lain, bidang sosial ini mencakup berbagai aspek yang luas, seperti tanggung jawab untuk turut serta memajukan kegiatan penduduk pada semua jenjang, mendorong dan mendukung terselenggaranya kegiatan penduduk nonformal, mendorong kreatifitas masyarakat di bidang seni dan budaya. Di samping itu merupakan suatu hal yang diharapkan pihak perusahan dapat memberikan kepedulian bagi masyarakat setempat. Untuk menciptakan kesejahteraan bagi masyarakat setempat.

Kegiatan CSR yang dilakukan oleh perusahaan yang menerapakan konsep triple buttom line yakni keuntungan, masyarakat dan lingkungan ini mencakaup terhadap segala aspek yang diperlukan dalam masyarakat. Seperti yang telah direncanakan oleh Bappenas untuk akses terhadap keadilan bagi masyarakat miskin terdapat tiga hal pokok yang direkomendasikan yakni; ${ }^{19}$ 1. Pendidikan dan pemberdayaan hukum berbasis masyarakat, yang meliputi hak mendapatkan informasi dasar mengenai hak-hak dibidang ekonomi, kesehatan dan lain-lain. 2. Pengembangan keparalegaan di Indonesia, sebagai pendampingan masyarakat setempat yang dididik, dilatih dan didampingi untuk dapat menjalankan fungsi pemberdayaan masyarakat, advokasi dan penanganan kasus, dan 3. Mengintegrasikan pemberdayaan hukum dan program pemberdayaan masyarakat, Integrasi ini penting karena beberapa alasan: (i) pemberdayaan hukum lebih efektif dan mudah dipahami jika sejalan dengan persoalan atau kegiatan sehari-hari kelompok masyarakat sasaran; (ii) meminimalisasi penggunaan sumber daya dan biaya untuk membangun struktur program baru; (iii) keuntungan timbal balik, program

\footnotetext{
${ }^{19}$ Kelompok Kerja Akses terhadap Keadilan, Op Cit.., hlm 179-180
} 
pemberdayaan ekonomi mendapat keuntungan karena tersedianya mekanisme penanganan masalah (korupsi, penyalahgunaan dana, penyimpangan pelaksanaan program) sementara pada saat yang sama masyarakat mendapat kesempatan untuk mendapat pendampingan dalam pendidikan dan bantuan hukum, dan (iv) keberlanjutan program yang lebih terjaga. Dengan demikian kegiatan yang dilakukan oleh perusahaan dengan menggunakan istilah CSR ini sejalan dan searah dengan pembangunan nasional, sehingga hal tersebut penulis berpendapat bahwasannya kegiatan CSR ini merupakan salah satu acess to justice bagi masyarakat. 


\section{PENUTUP}

Perusahaan di setiap Provinsi dan kota telah menyebabkan banyak dampak, baik dampak positif maupun dampak negagatif akibat kegiatan usaha yang mereka lakukan,, jika perusahaan-perusahaan tersebut bekerjasama dengan pemerintah dan masyarakat setempat dalam pembangunann sosial tentu menjadi potensi yang sangat baik dalam pembangunan kesejahtraan masyarakat. Jika perusahaan dengan melakukan kegiatan CSRnya, pemenrintah dengan melakukan pelayanan sosial dan masyarakan memberikan dukungan dan kerjasma dalam setiap kebijakan.

Setiap kegiatan yang dilakukan oleh perusahaan yakni kegiatan CSRnya dirasa merupakan suatu bentuk atau salah satu dari perwujudan acess to justice bagi masyarakat. Hal ini terlihat dari seluruh kegiatan yang dilakukan oleh perusahaan yang memperhatikan kepedulian perusahaan terhadap masyarakat sekitar dan masyarakat umum. 


\section{DAFTAR PUSTAKA}

\section{A. BUKU}

Faza, Mukti, Tanggung Jawab Sosial Perusahaan di Indonesia Studi tentang Penerapan Ketentuan CSR pasa Perusahaan Mulitinasional, Swasta Nasional dan BUMN di Indonesia,Yogyakarta: Pustaka Pelajar. 2010 .

Kelompok Kerja Akses terhadap Keadilan, Strategi Nasional Akses Terhadap Keadilan, Jakarta: Badan Perencanaan Pembangunan Nasional (BAPPENAS). 2009.

Suharto, Edi, Pekerjaan Sosial Didunia Industri Memperkuat CSR (Coorporate Social Responsibility), Bandung: Alfabeta. 2009.

Sukisno, A dan I Cenik, A, Etika Bisnis Dan Profesi tantangan Membangun Manusia Seutuhnya Edisi Revisi, Jakarta Selatan: Salemba Empat. 2013.

\section{B. INTERNET}

Anual Report 2012 HM Sampoerna

Badan Pusat Statistik Nasional https://www.bps.go.id/dynamictable/2016/01/18/1119/jumlahpenduduk-miskin-menurut-provinsi-2007-2019.html UndangUndang Dasar Negara Republik Indonesia Tahun 1945 Pasca Amandemen

Elok Dyah Messwati, Kompas.com "70 Persen Kerusakan Lingkungan akibat Operasi ttps://regional.kompas.com/read/2012/09/28/17313375/70.Persen.K erusakan.Lingkungan.akibat.Operasi.Tambang.

Harian Republika 24 Maret 2008

http://www.antaranews.com/berita/321819/ratusan-ikan-mati-diduga-akibatlimbah-pabrik di akses pada 20 Januari 2014

Jejen Hendar , 2017 Corporate Social Responsibility (CSR) Dalam Prespektif Hukum Islam, Jurnal Hukum Syiar Hukum, Vol. 15, No. 1

Kompas 23 Februari "Kontrol Kerusakan Lingkungan Lemah" 
Muhammad Imam Purwandi, 2013 Al-Qordh dan Al-Qordul Hasan sebagai Wujud Pelaksanaan Tanggung Jawab Sosial Perbankan Syari'ah (Studi Pada PT Bank Muamalat Indonesia Tbk), disertasi, Yogyakarta: Pasca Sarjana UII.

Nana Sudiana, CSR dan Kepedulian Perusahaan, 2011 dalam http://csr.pkpu.or.id/article/csr-dan-kepedulian-perusahaan dikutip pada 25 Januari 2014

Yuli Pujihardi, "Bakar Dahulu, CSR Kemudian” Republika Senin 16 Nov 2015, https://republika.co.id/berita/nxwjsq29/bakar-dahulu-csr-kemudian, 